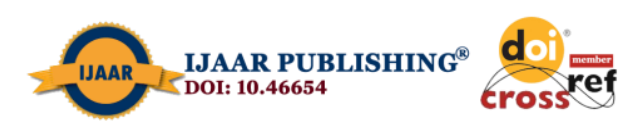

International Journal of Advanced Academic Research | ISSN: 2488-9849

Vol. 7, Issue 5 (May, 2021) | www.ijaar.org

Journal DOI: www.doi.org/10.46654/ij.24889849

Article DOI: www.doi.org/10.46654/ij.24889849.s71599

\title{
GOSPEL MINISTERS AND THE HOME FRONT: PROBLEMS AND PROSPECTS
}

\author{
Afolabi Samuel Oluseyi, Ph.D. \\ Email: samseyiafolabi@gmail.com \\ Telephone: +234803 4127021

\section{Biographical Sketch of the Author}

AFOLABI, Samuel Oluseyi holds a Ph.D. in Religious Studies from the University of Ibadan, Nigeria. He is a Lecturer in Church History, Church Planting and Growth at Michael Olowere College of Theology (MOCOT), Ashi, Ibadan, Oyo State, Nigeria.

$\mathrm{He}$ is also an alumnus and a lecturer of Missions and Exposure Training - MET (Pentecostal Assemblies of Canada), Pretoria, South Africa.

He is the Senior Pastor of Christ Apostolic Church All Nations Assemblies, Ibadan, Nigeria.

\begin{abstract}
The research work investigated Gospel ministers and their homes with the purpose of knowing their success level at the home front. The study examined whether the homes of Gospel ministers who are supposed to be worthy examples to the flock are the ideal homes that fulfil God's plan and purpose for marriage. This research work focused on five 5 Local Government Areas in Ibadan, Nigeria. Data were gathered through the use of structured oral interview, questionnaire, archival materials and bibliographical search. The findings of the study revealed that there are some factors threatening the stability of the homes of Gospel ministers. Such factors include poor finances, busy ministerial schedules, being separated from the family due to ministerial assignments, sexual immorality and the uncooperative attitude of their wives. Useful suggestions were offered to help Gospel ministers manage their homes and make such the ideal homes that would fulfil God's purpose and be worthy of emulation to all and sundry.
\end{abstract}

Keywords: Gospel Ministers, Homes, Marriage, God's Purpose. 


\section{INTRODUCTION}

Marriage is God's oldest institution and it was established when God gave Eve to Adam in Genesis 2:18. "And the Lord said, 'it is not good that the man should be alone;' I will make him a helpmeet for him." In His plan and purpose, God instituted the home to be fruitful, harmonious and enjoying. God intended the home to be a place where a couple will experience oneness, peace, happiness and mutual benefit. This is the reason why God Himself solemnized the first marriage; giving the first woman to the first man in matrimony. Since the time when God instituted marriage up till now, it has been generally accepted in most societies and cultures all over the world.

\section{STATEMENT OF PROBLEM}

Quite a number of people enter marriage with great expectations of marital bliss but such people never expect the difficulties they eventually encounter in the relationship. They think marriage is a bed of roses with no pains attached to it. After a period of time, thwarted dreams, loneliness, regrets and self-pity are the noticeable outcomes of such unions, leaving behind feelings of bitterness and resentment.

Contrary to God's plan and purpose for instituting marriage, many marriages are in shambles today. Husbands are enduring their wives and vice versa and the children are also enduring the disharmony and chaos at home. It has become common for husbands and wives to live like cats and dogs at home and it has come to stay as a normal way of living in many homes. The "yet to marry" singles, due to the failed marriages they have witnessed, tend to believe that it is not possible to have a happy marriage/home. Hence, we see people who enter into marriage with the thought of its possible failure.

Unfortunately, the ministers of the Gospel whose marriages and homes are supposed to be real examples of ideal homes are not exempted from the negative experiences of failed marriages. The homes of many Gospel ministers are far from being the ideal homes that members of the church can emulate. Lack of genuine love, peace and unity; breakdown of trust, bitterness, resentment and regrets are the hallmarks of many a home of our celebrated and highly esteemed church leaders.

Some wives of Gospel ministers are highly disappointed due to the ill-treatment they receive from their husbands. These women are nursing the seeds of hatred and hostility towards the work of God because of 'a husband' who won't take time to listen or take care of his family due to his tight ministerial schedule and "love for the ministry."

There are church leaders who preach, teach, counsel and visit people all round the clock at the expense of their homes. There are ministers' children whose fathers spend more time praying for and counseling church members rather than engage their children in one-on-one conversation at home.

Many celebrated and successful ministers of this generation are successful in other areas but they have failed woefully at home. Some of them have plunged into chaos, confusion and immorality because of marital crises. What a painful thing! It is the utmost desire of God that the homes of His beloved servants would be happy, joyful and worthy of emulation for all and sundry.

\section{THE ORIGIN AND DEFINITION OF MARRIAGE}

The Holy Bible traces the historical origin of marriage to the beginning of existence of human beings. According to Genesis 2:20-24; God caused Adam to fall into a deep sleep and He took one of the ribs of Adam and made a woman, Eve, for him. As a result, a man will leave his parents and 
cleave unto his wife. This indicates that marriage institution is as old as the existence of human beings since Adam and Eve happened to be the first human beings created by God.

From the foregoing, it is established that God created Eve for Adam as a wife and companion. As Sam Adeleke remarks, ${ }^{1}$ the deficiency in Adam was completed with the creation of Eve. He stated that Eve was "a helpmeet for Adam," complementing partner and companion, an indispensable source of procreation, keeper of the home, and a vital treasure in the home. ${ }^{2}$

Adeleke $^{3}$ also states some reasons why God instituted marriage. He mentions companionship, mutual understanding, expression of love and affection, source of help and comfort for each other, and procreation.

There are lots of definitions available from different literatures consulted. Akinpelu ${ }^{4}$ stated that this variety of definitions makes a universal definition of the concept impossible. Leach ${ }^{5}$ asserts that any attempt at a universal definition of marriage is inevitably "vain." The controversy still rages among scholars concerning the definition that will be widely acceptable. However, for the purpose of this study, we shall adopt a simple definition in agreement with Seweje. ${ }^{6}$ He defines marriage as "a union, a coming together of man and woman who have been in love and have agreed and prepared to live their lives together in accordance with God's standards".

In legal sense, marriage is a contract between one or more males and one or more females for the establishment of a family. Oluwusi stated that "marriage is a contract whereby the parties thereto enter into legal relations involving right and obligations". ${ }^{7}$ However, it is the mutual consent of the parties that brings agreement into being.

\section{THE IMPORTANCE OF MARRIAGE}

The subject of marriage according to Oke ${ }^{8}$ is such an important one in human life that at one stage or the other, man has to take a decision on it. Marriage is very crucial to the future of any man or woman. Hardly is there any normal and right-thinking human being who does not have a reason to think about it at one time or the other in life. The importance of marriage could be seen in its worldwide acceptance among people of all races, culture and religion. Akinpelu ${ }^{9}$ states that

${ }^{1}$ Adeleke, S. A. (2007) Marital adjustment and conflict resolution in the home. (Course note of Christ's School of Ministries, CAET, Ibadan, Nigeria.). p 1-3.

${ }^{2}$ Akande, D. (2007). Back to basics in Marriage and Family Living. (Course note of Christ's School of Ministries, CAET, Ibadan, Nigeria.) .p 2-4.

${ }^{3}$ Ibid

${ }^{4}$ Akinpelu, V. O. A. (2000). Financial management and marital harmony among people of different socio-cultural ethnic groups in Nigeria, with particular reference to Ibadan Municipality.

(Unpublished B.A. Long Essay) Department of Guidance and Counselling, Faculty ofEducation, University of Ibadan. p 10-15.

${ }^{5}$ Leach, W.H. (1961). The Cokesbury marriage manual. UK. Abingdon Press.

${ }^{6}$ Seweje, N. (2007). The place of family in God's plan. (Course note of Christ's School of Ministries, CAET, Ibadan, Nigeria.).p 1-4.

${ }^{7}$ Oluwusi, W. 2007. Law and marriage. (Course note of Christ's School of Ministries, CAET, Ibadan, Nigeria.) p 2-5.

${ }^{8}$ Oke, E. O. (2004). Integrating the Christian home in the face of conflicts and crises at this end time. A project submitted to Christ's School of Ministries, CAET, Ibadan, Nigeria. p 3-5.

${ }^{9}$ Akinpelu, V. O. A. (2000). Financial management and marital harmony among people of different socio-cultural ethnic groups in Nigeria, with particular reference to Ibadan Municipality. 
marriage institution can be said to be of worldwide acceptance because hardly can anyone cite a society in the world where it does not function or exist, though the way of practicing it may differ. Its importance can also be found in the fact that anthropologists, philosophers, marriage counselors, educationist, psychologists and ministers of religion have given absolute and necessary attention to it. In the present complex psychological situation of the world, marriage occupies a key position. It is certain that in human society, the world over, the issue of marriage is still as topical today as it was many years ago. ${ }^{10}$

Akinpelu ${ }^{11}$ also asserts that marriage is essentially a communal activity, and this is why it is rooted and grounded in the society. In every society, the institution of marriage has legal backing in terms of who to marry, types of marriage, marriageable years for males and females, society's acceptance of the would-be couples and time or years that divorce can be proposed by any of the partners. The relevance of marriage to the people of Africa can also be seen in what Radcliffe Brown asserts. ${ }^{12}$ According to him, "for the understanding of any aspect of the social life of an African people's economic, political or religious, it is essential to have a thorough knowledge of their system of kinship and marriage."

In the Nigerian society for instance, Akinpelu ${ }^{13}$ states that marriage is taken as one of the strong and reliable pre-requisites to responsible adulthood. Males and females that reach marriageable ages and refuse to get "hooked" at this appropriate time are not generally regarded as responsible, right thinking or sane persons. To the society, they are regarded as non-conformists to societal demand and as a result, the society also frowns at them. In fact, the society's response to such a fellow will frustrate any attempts he/she makes in any field, be it social, political, cultural and economic. It may be because of this society's acceptance and attitude to marriage that forced Mbiti to assert that "to die without getting married and without children is to be completely cut off from the human society, to become disconnected, to become an outcast and to lose all links with mankind. ${ }^{14}$

\section{THE IDEAL HOME}

In God's plan and purpose, He instituted marriage to be fruitful, harmonious and enjoying. According to Omojola, ${ }^{15}$ God intended the home to be a place where the couple will experience oneness, peace, happiness and mutual benefits. Adebara ${ }^{16}$ believes that whenever any family falls into God's plan, that family becomes an ideal family, fulfilling the purpose of God. Any home that does not fulfil God's vision is not the ideal home and it is not in line with the will of the Almighty God.

(Unpublished B.A. Long Essay) Department of Guidance and Counselling, Faculty of Education, University of Ibadan. p 10-15.

${ }^{10}$ Leadership Ministries worldwide. (1996). What the Bible says to the ministers: The ministers' personal handbook. Chattanooga, TN Alpha-Omega Ministries.

${ }^{11} \mathrm{Ibid}$

${ }^{12}$ Radcliffe B, Reginald, A. (1950). African System of Kingship and Marriage. London. Oxford University Press.

${ }^{13}$ Akinpelu V.O.A. Financial management. ..p 16

${ }^{14}$ John M. (1973). Love and marriage in Africa. London Longman Publisihing.

${ }^{15}$ Omojola, E. B. (1994). Coping with pressures in marriage. Ibadan, Agape Publications. p 15-20.

${ }^{16}$ Adebara, S., The family in God's plan. Ibadan. Adonai Consult Limited, 1991.p 20-25. 
The ideal or God kind of home cannot be attained by accident. Babalola ${ }^{17}$ asserts that several varieties or ingredients must be put together to produce one mixture that has a pleasing effect. Some of such necessary ingredients are: leaving and cleaving, maturity, acceptance, effective communication, appreciation of each other, agreement, love and submission.

\section{THE CHALLENGES FACING GOSPEL MINISTERS' HOMES Poor Finances}

Many Gospel ministers are poorly paid by their churches. Their salaries and monthly take homes are nothing to write home about. Some of these ministers have no stable salaries and they have no other means of income in form of secular jobs. They are on full time ministerial duties and pitifully, they live on the charity of their church members and well-wishers. At times they experience days of abundance but often than not they experience days of financial hardships. As a result of their poor remunerations, they find it difficult to meet the financial needs of their families. Most ministers' wives and children never enjoy a great abundance of finances especially in the early days of their ministerial assignments. Their families hardly have good meals to eat or boast of a wardrobe with beautiful clothes. Some of them find it extremely difficult to pay their children school fees and give them good and qualitative education. Many of their children have unfulfilled expectations due to the financial inability of their parents.

The pitiful financial state of these ministers is not without its resultant effects. The first effect is lack of submission on the part of their wives. A woman finds it difficult to submit to a man who cannot take care of her and meet the financial needs at home. It takes an extremely spirit filled woman to encounter such and remain submissive and controllable.

When parents fail to meet the financial needs of their children and such children resort to begging or fending for themselves, they are likely to become delinquent, rascal and uncontrollable. Hence, the wayward behaviours of many ministers' children.

\section{Busy Ministerial Schedule}

Many ministers usually have tight ministerial schedules that make it difficult or impossible for them to have time for their families. For some of them, this tight work schedule is unavoidable due to the increasing growth and expansion of their ministries. Hence, these church leaders preach, teach, counsel, pray for and visit people all round the clock at the expense of their homes. According to Mike Murdock ${ }^{18}$, there are ministers who spend more time in the church with their members rather than have time for intimate relationship with their wives and kids at home. Some children rarely see their fathers during the daytime except at late hours of the night when they are almost going to bed. Some ministers prefer to be in the church throughout the week, coming home only on weekends.

According to 1 Tim. 3:4-5 and Titus 1:6, Gospel ministers must rule their own households and rule it well. The house is a miniature of the church; it is the proving ground for leadership in the church. The minister is the head and leader of his wife and children. This does not mean he is the dictator, tyrant or bully of the home. He should lead them all in the building of a loving, joyful and peaceful home and in the fulfilment of their lives' calling and task upon the earth. He must not allow his children to disobey and rebel. He is to take the leading role in controlling his home for Christ and his kingdom. Mike Murdock asserted that if Gospel ministers will perform this God given role, they

\footnotetext{
${ }^{17}$ Babalola, D. (2007). Blending factors. (Course note of Christ's School of Ministries, CAET, Ibadan, Nigeria.) $\mathrm{p} 1-2$.

${ }^{18}$ Murdock, M. (1986). The young minister's handbook. Dallas, Texas, Mike Murdock Evangelistic Association.
} 
must not allow their ministerial tasks to hinder them. Being busy doing God's work is not an excuse for the failure of their homes to become role model to the church and society. ${ }^{19}$

\section{Living Apart Temporarily or Permanently}

This point is similar to the one discussed above about busy ministerial schedule. In most cases it is the issue of increasing ministerial duties and assignments (especially outside the location of the family base) that leads to the family being temporarily or permanently separated. There are Assembly Pastors who are transferred to newly established branches of their churches outside or far away from the family location and they may not be able to take their wives and children along. In some cases, the problems of accommodation, jobs for their wives and education of the children don't allow the families to shift base to their new locations with their breadwinners (the Pastors).

There are also Missionaries, itinerant Evangelists and General Overseers who have to travel for months without seeing their spouses or children. It is not in all cases and on all occasions that it is possible for them to carry their families along in their journeys.

According to Mike Murdock, the distance from their families makes them vulnerable to the attacks of the enemy, mentally, emotionally, and sexually. ${ }^{20}$ Since God's purpose for marriage is oneness and togetherness of couples, this purpose is being defeated when couples stay/live apart. Gospel ministers should seriously see to it that they stay together, talk together, play together, pray and do things together with their spouses. They should avoid being apart from their spouses as much as possible for long periods. When they have to move, they should do so together and when such is not possible the period of separation should not be prolonged. ${ }^{21}$

\section{Sexual Immorality}

If care is not taken, the issues raised above may lead to sexual immorality for Gospel ministers. When a minister is too busy to have time together with his spouse and he is also physically separated from the wife, there is the tendency for him to be sexually starved. This makes him vulnerable to the attacks of the enemy through strange women. Many ministers have become victims in this area.

In most cases, women outnumber men in the number of church members, and counselees who come to ministers for counselling. Some of these women have good intentions while some of them have bad intentions and ulterior motives towards the male ministers. In a case where a man of God is separated from his wife and sexually starved, it can be easy for the devil to use any of these strange women to attract the minister into sexual immorality unless the minister is God fearing, Spirit filled and highly disciplined. Even in cases where a minister is not physically separated from the wife and he is not sexually starved, there are seasons and times for satanic attacks. This cannot be overlooked as it is a common phenomenon in pastoral and counseling ministry. There have been cases of sexual scandal involving ministers and female church members or counselees and these incidences usually threaten the peace and stability of the homes of such ministers.

\section{Child training and upbringing}

According to 1 Tim. 3:4 and Titus 1:6, a minister must have God fearing and faithful children who are above reproach. They must not be loose in morals and conducts or be unruly and disorderly. The children must be taught and brought in the fear of God. In order to have an ideal home, ministers

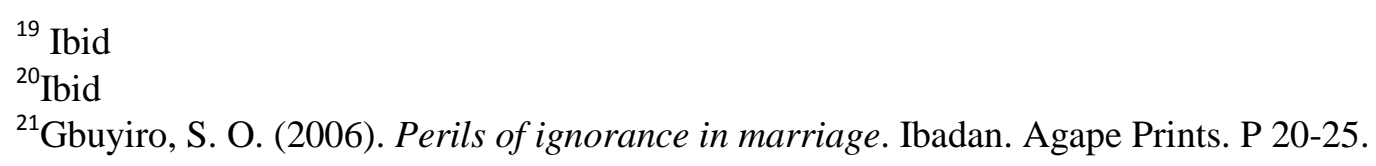


must train their children in spiritual and secular matters. Both parents should make it a point of duty to train their children in the way of the Lord in order to prevent the devil from penetrating into their home through their children. According to Osuntokun ${ }^{22}$ (2004), both parents are evangelists who are expected to evangelize their children.

It is a pity that some ministers leave no stone unturned to secure the best secular education for their children but they do not care about the spiritual welfare of the children. These children have little or no knowledge of God and spiritual things. Though these ministers have grace, gifts and anointing of God upon them, they do not bother to impart these into the lives of their children and give these children sound spiritual footing.

Another pitiful thing is the fact that due to the busy work schedule of some pastors and church leaders (as earlier discussed above), they have little or no time to oversee the training and spiritual welfare of their children. The Biblical case of Eli who neglected the training and spiritual wellbeing of his children to his own peril has become a common thing in the homes of many Gospel ministers today. So rampant are such cases that people erroneously now tend to believe that ministers' children are always wayward. However, this is not supposed to be so.

Gospel ministers should see to it that they do not get busy working for God at the expense of their homes and the proper training of their children. While they are busy laboring over the souls of other people, they should not neglect their own children and allow them to perish. Their stories should not be like that of the biblical lady who said, "Do not stare at me because I am dark, because I am darkened by the sun. My mother's sons were angry with me and made me to take care of the vineyards; MY OWN VINEYARD I HAVE NEGLECTED.” SOS 1:6.

\section{Non-supporting wives}

Gospel ministers' wives are expected to be helpful companions and co-workers for their spouses in God's vineyard. They are to use their spiritual gifts and do all within their power to help their husbands and accelerate the growth and success of their ministries. However, this is not the case in some ministers' homes. Some wives of Gospel ministers are highly disappointed due to the ill treatment they receive from their husbands. Mike Murdock believed these women are harboring the seed of hatred and hostility in their hearts towards the work of God because of a husband who won't take time to listen or take care of his family because of his tight ministerial schedule and "love for the ministry." 23 A woman may not support her husband's ministry if she discovers that her husband does not have time for her and take interest in her welfare and that of her children. Another thing that may make ministers' wives not to support their husbands' ministries is the poor financial conditions of their husbands. As stated earlier, a woman finds it difficult to submit to a man who cannot take care of her and meet the financial needs at home. It takes an extremely spirit filled woman to be in such a position and remain submissive and controllable.

Furthermore, ministers' wives may not support their husbands if such do not appreciate their wives. Some ministers are in the habits of complaining about their wives. They see nothing good about their wives, they do not respect their wives' views on issues at home and in the church, and they even accuse them of being bewitched and being opponents of their ministries. When a woman is subjected to this type of treatment she won't be encouraged and motivated to support her husband no matter how highly anointed the man may be.

\footnotetext{
${ }^{22}$ Osuntokun, M. (2004). Path. to God-kind home. Ibadan. Bread and life publication, 2004.

${ }^{23}$ Murdock, M. The young minister's handbook.:.
} 


\section{RECOMMENDATIONS AND CONCLUSION}

Based on the findings of this research work, the following recommendations are germane.

1. Concerted efforts should be made by churches, Christian ministries to pay their ministers good salaries that can help them adequately meet the financial needs of their families. This is enjoined by the Scriptures in Matt. 10:9-10 and 1 Tim. 5:17-18. Churches and Christian ministries should have good welfare packages for the upkeep of their ministers and their homes. Church members should also seek to take good care of God's servants as enjoined by the Scriptures in Matt. 10:9-10 and 1 Tim. 5:17-18.

2. Gospel ministers should always try as much as lies in their power to provide for the needs of their families. They should pray much and believe God for the provision of their needs without compromising their calls or standards of holiness.

3. If permitted by God, ministers should seek to have some form of secular business or investments that could help them raise money for the upkeep of their families. Not all ministers are called by God to serve on full time basis. It is not a sin for a minister to have business ventures that can generate income for him if God has not ordered him not to engage in such. A good example in this regard is that of Paul who doubled as an evangelist and a tentmaker. He supported himself in the ministry with the proceeds from his tent making business. See Acts 18:1-3, 20-34.

4. They must not allow their ministerial assignments to hinder them from being available at home regularly to oversee the training and upbringing of their children. They must labour to make their children become role models in the Church and the society. They must share the vision of their ministries and spiritual tasks with their spouses and children. Their ministries must start from home. They need to carry their family members along as partners in their ministries. They should also know that their homes are expected to display the true picture of Christ. All eyes are on them expecting to see Christ in them. In this regard they must not fail.

5. They must not form the habit of staying apart from their spouses so as not to give room for loneliness, sexual immorality or other forms of Satanic attacks that may come in through their separation from their homes. When traveling out of the family base they must regularly be in touch with their homes. When and where it is possible, they should take their spouses along with them.

6. They should be open to their wives whenever they sense that Satan is around the corner to tempt them with sexual immorality. They should also watch and pray. Their wives should endeavor to pray much for them on such occasions and lift them up in God's presence instead of condemning them.

7. Wives should seek to support their husbands' ministries and not become hindrances. They should see their husbands' ministries as theirs. If God calls the husband, the wife automatically shares in the call, in whatever area she can assist her husband.

8. Ministers should learn to appreciate the efforts and inputs of their wives towards the growth and success of their ministries. They should not disregard meaningful advice, views and comments of their wives. 
Journal DOI: www.doi.org/10.46654/ij.24889849

Article DOI: www.doi.org/10.46654/ij.24889849.s71599

9. In spite of all odds, ministers should labour above all things to prepare their family members for the rapture. They must make sure they make heaven at last with all their family members. 